\title{
Bazı önemli tıbbi bitkilerin antioksidan ve antikanser etkilerinin araştırılması
}

\author{
Rabia TOP ${ }^{1}$, Yavuz ERDEN ${ }^{1 *}$, Suat TEKİN ${ }^{2}$ \\ ${ }^{1}$ Bartın Üniversitesi Fen Fakültesi Moleküler Biyoloji ve Genetik Bölümü, Bartın \\ ${ }^{2}$ Inönü̈ Üniversitesi Tıp Fakültesi Fizyoloji Anabilim Dalı, Malatya \\ (ORCID: 0000-0002-3306-1 163) (ORCID: 0000-0002-2807-6096) (ORCID: 0000-0002-2757-1802)
}

\section{$\ddot{O} z$}

Tıbbi açıdan önemli bitkiler binlerce yıldır birçok hastalığın tedavisi amacıyla kullanılmaktadır. Buna ek olarak modern eczacılıkta birçok bitki bileşiği ilaç ham maddesi veya yeni ilaçların yapımında önemli bir yere sahiptir. $\mathrm{Bu}$ çalışmada tıbbi öneme sahip kudret narı (Momordica charantia), pepino (Solanum muricatum) ve altın çilek (Physalis peruviana) bitkilerinin meyvelerinden elde edilen özütlerin biyolojik etkinliklerinin ortaya konulması amaçlanmıştır. Bitkilerin meyve özütleri \%80'lik etanolde hazırlandıktan sonra toplam polifenol içeriği FolinCiocalteu reaktifi kullanılarak spektrofotometrik olarak ölçüldü. Bitki örneklerinin serbest radikal giderme etkisi DPPH serbest radikali kullanılarak belirlendi. Özütlerin insan over ve meme kanseri hücre hatları (sıyasıyla A2780 ve MCF-7) üzerine sitotoksik etkileri MTT yöntemi kullanılarak belirlendi. Bitki örneklerindeki toplam polifenolik düzeyin en düşük $138,14 \pm 12,15$ ve en yüksek $415,71 \pm 36,89 \mu \mathrm{g} / \mathrm{gr}$ gallik asit düzeyinde olduğu belirlendi. Bütün özütlerin düşük seviyede antioksidan etki sergilediği saptandı. Son olarak over ve meme kanseri hücre serilerine uygulanan özütlerin güçlü sitotoksik etki gösterdiği belirlendi $(\mathrm{p}<0.05)$. Sonuçta her üç bitki örneğinin de antioksidan etkilerinden ziyade yüksek antikanser etkiye sahip olduğunu bizlere göstermektedir. Her üç örneğinde söz konusu kanser türleri üzerine etkilerini aydınlatmak için ileriki çalışmalara ihtiyaç vardır.

Anahtar kelimeler: Antioksidan, Momordica charantia, Physalis peruviana, Sitotoksisite, Solanum muricatum.

\section{The investigation of antioxidant and anticancer effects of some importance medical plants}

\begin{abstract}
For thousands of years, plants have been used for the treatment of many diseases. In addition, in modern pharmacy many plant compounds have an important place in the production of pharmaceutical raw materials or new medicines. The aim of this study was to determine the biological activity of extracts obtained from the fruits of the medical important bitter melon (Momordica charantia), pepino (Solanum muricatum) and goldenberry (Physalis peruviana). The total polyphenol content of the samples was measured spectrophotometrically using FolinCiocalteu reactivity. The DPPH free radical scavenging effect of plant samples was determined and antioxidant capacities were determined. In addition, the cytotoxic effects of the samples on human over and breast cancer cell lines (A-2780 and MCF-7, respectively) were determined using MTT method. As a result of the study, it was determined that the highest total polyphenol content was in the case of potency and the lowest content was in the case of pepino. All three plant samples revealed the effect of free radical elimination of DPPH dependent predation. Finally, it was determined that all three plant samples showed high cytotoxic effect on both human over and breast cancer cell lines $(\mathrm{p}<0.05)$. Results show us that in all three plant samples it has a significantly higher anticancer effect than antioxidant effect. With the extensive studies to be carried out after that, the mechanism of the effect can be enlightened and contribute to new treatment approaches.
\end{abstract}

Keywords: Antioxidant, Cytotoxicity, Momordica charantia, Physalis peruviana, Solanum muricatum.

"Sorumlu yazar: yerden@bartin.edu.tr

Geliş Tarihi: 19.11.2018, Kabul Tarihi: 15.03.2019 


\section{Giriş}

Farmakolojik olarak tıbbi bitkiler neredeyse tüm medeniyetler için her zaman ön planda olmuştur. $\mathrm{Bu}$ bitkiler hastalıkların tedavisi ve muhtemel salgınların önlenmesi, yemeklere lezzet katmak ve gidaları muhafaza etmek amacıyla kullanılmaktadır. Tıbbi bitkiler geleneksel ilaçların zengin kaynakları olarak kabul edilir ve bu bitkilerden sentetik ilaçların çoğu üretilir. Bitkiler tarafından üretilen ikincil metabolitler genellikle dünya genelinde kullanılan bitki türlerinin biyolojik özelliklerinden sorumludur $[1,2]$. Bitkilerde bulunan alkoloidler, tanenler, flavonoidler ve fenolik gibi bileşikler insan sağlı̆g için terapötiktir [3, 4].

Tıbbi bitkiler insanlığın gelişiminde önemli bir rol oynamaktadır. Binlerce yıldır var olan geleneksel tıp sistemlerinin temelleri bitkilerden oluşmaktadır. Hastalıkların tedavisinde kullanılan geleneksel tıp pratiği özellikle Çin, Hindistan, Japonya, Pakistan, Sri Lanka ve Tayland'da yaygındır. Örneğin toplam tıbbi tüketimin yaklaşı \% 40' 1 Çin tarafından yalnız başına geleneksel kabile ilaçlarına atfedilmektedir Diğer yandan bitkisel tıbbi preparatlar, Japonya'daki ana farmasötik ürünlere göre daha fazla talep görmektedir $[2,5]$. Dünya Sağlık Örgütü'nün yaptığı araştırmalara göre tedavi amaçlı kullanılan tıbbi bitkilerin sayısı 20.000 civarındadır [1].

Tıbbi bitkilerin sağlık üzerine etkilerinin araştırılması yeni ilaçların keşfi veya tasarımı için önemlidir. Bitkiler geçmişte, günümüzde ve gelecekte farklı hastalıkların tedavisinde kullanılan ilaçların yapımı için en iyi kaynak olmaya devam edecektir [6]. Örneğin aspirinin keşfedilme öyküsü, sögüt ağacı kabuğunun ağrı kesici ve ateş düşürücü olarak kullanıldığ1 3500 yıl öncesine kadar uzanmaktadır. Aspirin şu anda dünyada en yaygın kullanılan ilaçtır ve başta kardiyovasküler ve serebrovasküler hastalıkların tedavisinde rolü nedeniyle geçen yüzyılın en büyük farmasötik başarı öykülerinden biri olarak kabul edilir [7]. Diğer bazı tıbbi öneme sahip bitkilerin kanser ve viral saldırı ile ilişkili hastalıklar dahil olmak üzere Hepatit ve AIDS gibi bir dizi ölümcül hastalığın tedavisinde etkin roller üstlendiği bildirilmektedir [8-10]. Bu tür bitkilerden elde edilen geleneksel ilaçlar, sentetik ilaçlara kıyasla daha az yan etkilere sahip olmaları ve bileşik kombinasyonunun sinerjik etkisinden dolayı da hastalıkların tedavisinde önemli bir yer tutmaktadır [2]. Bitki izolatlarından elde edilen ham madde kaynaklı tasarlanan birçok sentetik ilacın olmasına karşın, insanların maruz kaldığı hastalıkların çeşitliliği ve kişilerin hastalıklara farklı yanıtlar vermesi ilaç çalışmalarının önemini arttırmaktadır. Kabul edilebilir terapinin bilinen insan hastalıklarının sadece üçte biri için mevcut olduğu tahmin edilmektedir. $\mathrm{Bu}$ nedenle tıbbi öneme sahip türlerin biyolojik özelliklerinin ortaya konması gelecek çalışmalar için önemlidir [2].

Bu çalışmada ülkemizde de son zamanlarda üretimine başlanan ve tıbbi öneme sahip kudret narı (Momordica charantia), pepino (Solanum muricatum) ve altın çilek (Physalis peruviana) bitkilerinin meyvelerinden elde edilen özütlerin in vitro ortamda antioksidan ve antikanser etkilerini belirlemeyi amaçladık. Söz konusu bitkilerin potansiyel biyolojik etkinliklerinin ortaya konması bu kapsamda yapılacak yeni çalışmalara destek sağlayabilir.

\section{Materyal ve Metot}

\subsection{Bitki örnekleri}

Çalışmada kullanılan bitki örnekleri Bartın İli Çaydüzü mevkinde 2017 yılı Ağustos-Ekim ayları arasında toplandı. Toplanan meyve örnekleri \%80 etanol içerisinde 1:10 (gr/ml) oranında homojenize edildi. İşlem sonrasında homejenatın içerisindeki alkol oda sıcaklığında uçuruldu ve geriye kalan bitki özütünün toplam hacmi $10 \mathrm{ml}$ olacak şekilde distile su tamamlandı. Sonrasında hazırlanan bu stoktan 1 , 5, 25, 50 ve $100 \mathrm{mg} / \mathrm{ml}$ 'lik konsantrasyonlar hazırlanarak deneysel çalışmalarda kullanıldı. Bütün örnekler deneysel süreç boyunca $+4^{\circ} \mathrm{C}$ 'de muhafaza edildi.

\subsection{Toplam polifenol miktarının belirlenmesi}

Toplam polifenol konsantrasyonu Folin-Ciocalteu kullanılarak belirlendi [11]. Bu amaçla, 0,125 mL bitki özütü (son konsantrasyonu $100 \mathrm{mg} / \mathrm{mL}$ ) üzerine $0,125 \mathrm{~mL}$ Folin-Ciocalteu reaktifi ile $0,5 \mathrm{~mL}$ distile su ilave edilip oda sıcaklı̆ğında $6 \mathrm{dk}$ beklendi. Daha sonra bu karışım üzerine $1,25 \mathrm{~mL} \% 7^{\prime}$ lik $\mathrm{Na}_{2} \mathrm{CO}_{3}$ eklendi ve toplam hacim $3 \mathrm{~mL}$ olacak şekilde distile su ile tamamlandı. Reaktif karışımı 
vortekslendi ve oda sıcaklığında $90 \mathrm{dk}$ inkübasyona bırakıldı. Son olarak preparatın absorbans1 765 nm'de köre karşı okundu. Toplam polifenol miktarı, gallik asit standart eğrisi kullanılarak hesaplandı $\left(r^{2}=0.999\right)$ [12]. Sonuçlar ug/gr gallik asit eşdeğeri taze ağırlık olarak ifade edildi.

\subsection{Serbest radikal giderme aktivitesi}

Özütlerin antioksidan özellikleri DPPH serbest radikal temizleme aktivitesi belirlenerek değerlendirildi [13]. Serbest radikal olarak $25 \mathrm{mg} / \mathrm{L}$ DPPH (Sigma-Aldrich, ABD) metanolde hazırlandı ve kullanıma hazır hale getirildi. 3,9 mL DPPH çözeltisi üzerine $100 \mu \mathrm{L}$ hacimde bitki özütlerinin $1,5,25,50$ ve 100 $\mathrm{mg} / \mathrm{ml}$ 'lik konsantrasyonları eklendi. Karışım oda sıcaklığında karanlık bir ortamda 30 dk inkübasyona bırakıldı ve sonrasında absorbansları $517 \mathrm{~nm}$ 'de köre karşı spektrofotometrede okundu. Azalan absorbans, geriye kalan DPPH miktarı serbest radikal giderme aktivitesi olarak belirlenmektedir. Sonuçlar $\%=[($ Kontrol $A B S-$ ÖrnekABS $) /$ Kontrol $A B S)] \times 100$ göre hesapland.

\subsection{Antikanser özelliklerinin belirlenmesi}

\subsubsection{Hücre kültürü ve özütlerle muamele}

Çalışmamızda özütlerin antikanser etkisinin araştırılması için, insan meme kanseri hücre serisi (MCF7) ve insan over kanseri hücre serisi (A-2780) olmak üzere 2 farklı kanser hücresi kullanıldı. Her iki hücre hattı $25 \mathrm{~cm}^{2}$ kültür flasklarında, MCF-7 hücreleri DMEM medyum (içerisine \%10 FBS, $100 \mathrm{U} / \mathrm{mL}$ penisilin ve $0.1 \mathrm{mg} / \mathrm{mL}$ streptomisin ilave edilerek hazırlanan) ile A-2780 hücreleri ise RPMI-1640 medyum (içerisine $\% 10 \mathrm{FBS}, 100 \mathrm{U} / \mathrm{mL}$ penisilin ve $0.1 \mathrm{mg} / \mathrm{mL}$ streptomisin ilave edilerek hazırlanan) ile beslendi. Flasklar \%5'lik karbondioksitli inkübatörde (Panasonic, Japon) $37^{\circ} \mathrm{C}$ 'de ve nemli ortamda tutuldu ve hücrelerin medyumları haftada iki defa değiştirildi. Hücrelerin canlılığ $1 \% 0,4$ tripan blue kullanılarak belirlendi ve hücre canlılığının \%90 üstü olduğu durumlarda deneysel çalışmalara başlandı. Konfluent olan flasklardaki hücreler tripsin-EDTA solüsyonu kullanılarak kaldırıldı ve 96 kuyucuklu plaklara herbir kuyucuğa $15 \times 10^{3}$ hücre gelecek şekilde ekimi gerçekleştirildi. Test edilecek özütlerin 1 , $5,25,50$ ve $100 \mathrm{mg} / \mathrm{ml}^{\prime} l \mathrm{k}$ konsantrasyonları (final hacim $200 \mu \mathrm{l}$ ) hücrelerin içinde bulunduğu kuyucuklara ilave edildi ve 24 saat $\mathrm{CO}_{2}{ }^{\prime}$ li inkübatörde inkübasyona bırakıldı [14].

\subsubsection{MTT yöntemi}

İnkübasyon sonunda bitki özütlerinin hücre canlılığ üzerine etkisi MTT yöntemi ile tespit edildi. Öncelikle steril fosfat tamponu (pH: 7.2) içerisinde hazırlanan stok MTT (Sigma-Aldrich, ABD) solüsyonundan $0,5 \mathrm{mg} / \mathrm{mL}$ MTT çalışma solüsyonu hazırlandı. Hazırlanan bu solüsyondan 96 kuyucuklu plaklara $100 \mu \mathrm{L}$ ilave edildi. İnkübatörde 3 saat bekletildikten sonra plakalardaki hücrelerin optik dansiteleri $550 \mathrm{~nm}$ dalga boyunda ELISA cihazında (Synergy HT ABD) okundu. Kontrol kuyucukları okutularak, elde edilen absorbans değerlerinin ortalaması alındı ve bu değer \%100 canlı hücre olarak kabul edildi. Bitki özütü uygulanan kuyucuklardan elde edilen absorbans değerleri, kontrol absorbans değerine oranlandı ve yüzde canlılık değerleri hesaplandı $[14,15]$.

\section{5. İstatiksel analiz}

İstatistiksel analizler SPSS 20 (Windows) paket programı kullanılarak gerçekleştirildi. Verilerin normal dağılıma uygunluğu Shapiro Wilk testi ile değerlendirildi. Gruplar arasındaki farklıl1kların belirlenmesinde One Way ANOVA ve çoklu karşılaştırmalarda Tukey testi kullanıldı. Nicel veriler ortalama \pm standart sapma (Ort. \pm SS) olarak ifade edildi ve $p<0.05$ değerliği anlamlı kabul edildi.

\section{Bulgular ve Tartışma}

Bitki örneklerine ait toplam polifenol düzeyleri ve DPPH serbest radikal giderme etkisi Tablo 1'de gösterildi. Buna göre hazırlanan meyve özütleri kendi aralarında kıyaslandığında en fazla polifenol içerik kudret narının iç kısmından elde edilen özütte belirlenirken, en az polifenolik içerik ise kudret narının dış kısmında belirlendi. Bütün bitki özütlerinde artan doza bağlı olarak serbest radikal süpürme 
etkisinin arttığ1 ortaya konuldu. En yüksek konsantrasyon düzeyinde $(100 \mathrm{mg} / \mathrm{ml}) \% \mathrm{DPPH}$ serbest radikali süpürme etkisi altın çilek özütünde fazla iken, en düşük etki kudret narının dış kısmından elde edilene özütte görüldü.

Tablo 1. Bitki özütlerinin toplam polifenol düzeyi ve DPPH serbest radikal temizleme etkisi (\%).

\begin{tabular}{|c|c|c|c|c|c|c|}
\hline \multirow{2}{*}{ Bitki özütü } & \multirow{2}{*}{$\begin{array}{l}\text { Polifenol } \\
\text { düzeyi* }\end{array}$} & \multicolumn{5}{|c|}{ \% DPPH temizleme etkisi } \\
\hline & & $1 \mathrm{mg} / \mathrm{ml}$ & $5 \mathrm{mg} / \mathrm{ml}$ & $25 \mathrm{mg} / \mathrm{ml}$ & $50 \mathrm{mg} / \mathrm{ml}$ & $100 \mathrm{mg} / \mathrm{ml}$ \\
\hline $\begin{array}{l}\text { Kudret narı } \\
\text { (dış kısım) }\end{array}$ & $138,14 \pm 12,15$ & $2,41 \pm 0,95$ & $3,22 \pm 1,24$ & $5,36 \pm 0,89$ & $8,13 \pm 2,03$ & $10,51 \pm 2,78$ \\
\hline $\begin{array}{l}\text { Kudret narı } \\
\text { (iç kısım) }\end{array}$ & $415,71 \pm 36,89$ & $3,05 \pm 1,14$ & $3,65 \pm 0,95$ & $4,95 \pm 1,45$ & $7,52 \pm 1,56$ & $9,58 \pm 1,65$ \\
\hline Pepino & $176,23 \pm 26,71$ & $3,52 \pm 1,02$ & $3,89 \pm 1,36$ & $5,03 \pm 0,97$ & $8,16 \pm 2,87$ & $12,69 \pm 1,52$ \\
\hline Altın çilek & $207,85 \pm 21,56$ & $4,13 \pm 0,84$ & $5,17 \pm 1,78$ & $6,42 \pm 1,61$ & $11,65 \pm 1,86$ & $13,56 \pm 2,54$ \\
\hline
\end{tabular}

* Toplam polifenolik içerik $\mu \mathrm{g} / \mathrm{gr}$ Gallik asit eşdeğeri olarak ifade edildi.

Yapılan çalışmalar kudret narı, pepino ve altın çilek bitkilerinden elde edilen özütlerin flavanoid, polifenol ve vitamin içeriğine bağlı olarak antioksidan etki gösterdiğini bildirmektedir. Örneğin kudret narı [16-18] ve pepino [19] bitkilerinden elde edilen özütlerin in vitro olarak DPPH ve ABTS (2,2-azinobis-3-etilbenzotiazolin-6-sülforik asit) gibi serbest radikalleri giderici etki sergilediğini ve bu bitkilerin fitokimyasallar bakımından zengin birer kaynak olduklarını göstermektedir [17, 19]. Ayrıca altın çilek meyve özütünün de doza bağımlı bir şekilde DPPH serbest radikal giderme etkinliği gösterdiği ve bu etkinin referans antioksidan olarak kullanılan $\mathrm{C}$ vitaminine eş değer meydana geldiği bildirilmektedir [20]. Bitkiler, E ve C vitaminleri başta olmak üzere birçok vitamini ve antioksidan özellik gösteren karotenoidler, flavonoidler ve fenolik bileşikleri bünyelerinde fazlaca bulundurmaktadır [21]. Bitkilerin göstermiş oldukları antioksidan etkilerin bu bileşiklere bağlı olabileceği belirtilmiştir [22]. Çalışmamızda bitki örneklerinin toplam polifenolik düzeylerinin yanı sıra DPPH serbest radikal giderme kapasiteleri ortaya kondu. Örneklerin artan konsantrasyona bağlı olarak serbest radikal giderme etkilerinin de artış gösterdiği görüldü.

Kudret narı meyvelerinin dış ve iç kısımlarından elde edilen özütlerin insan meme ve over kanseri hücre serileri üzerine sitotoksik etkileri Şekil 1'de gösterilmiştir. Buna göre kudret narının dış kısmından elde edilen özütün bütün konsantrasyonları A-2780 ve MCF-7 hücrelerinde canlılığı önemli düzeyde azalttı (Şekil $1 \mathrm{~A}-\mathrm{B}, \mathrm{p}<0.05$ ). Kudret narının iç kısmından elde edilen özütte ise 50 ve 100 $\mathrm{mg} / \mathrm{ml}$ 'lik konsantrasyonların her iki hücre üzerine canlılığı önemli ölçüde azlttığı belirlendi (Şekil $1 \mathrm{C}$ $\mathrm{D}, \mathrm{p}<0.05)$. Buna karşın aynı özütün 1,5 ve $25 \mathrm{mg} / \mathrm{ml}$ 'lik konsantrasyonları A-2780 hücrelerinde canlılığı azaltıcı bir etki sergilemedi. Genel olarak meyvenin dış ve iç kısımlarından elde edilen özütlerin her ikiside MCF-7 hücre canlılığ üzerine daha azaltıc1 etkiler sergiledi.

Pepino özütünün insan over ve meme kanseri hücre hatları üzerine sitotoksik etkisi Şekil 2'de gösterilmiştir. Bitki özütünün uygulanan bütün konsantrasyonları her iki hücre hatt1 üzerine önemli düzeyde canlılığ 1 azaltıc1 etki sergiledi $(\mathrm{p}<0.05)$. Özellikle bu azaltıc1 etki düşük konsantrasyonlara kıyasla ( $1 \mathrm{ve} 5 \mathrm{mg} / \mathrm{ml}) 25 \mathrm{mg} / \mathrm{ml}$ ve üzeri konsantrasyonlar da daha belirgindi $(\mathrm{p}<0.05)$.

Altın çilek özütünün insan over ve meme kanseri hücre hatları üzerine sitotoksik etkileri sırasıyla Şekil 3A ve Şekil 3B' de gösterilmiştir. Altın çilek özütünün uygulanan bütün konsantrasyonları kontrole kıyasla her iki hücre hattında da benzer şekilde hücre canlılığını azalttı ( $\mathrm{p}<0.05)$. Bitki özütünün uygulanan konsantrasyonları birbiri içerisinde kıyaslandığı zaman ise $5,25,50$ ve $100 \mathrm{mg} / \mathrm{ml}$ 'lik konsantrasyonların hücre canlılığ 1 üzerine benzer etkiler ortaya koyduğu $(p>0.05)$ ve bu konsantrasyonların $1 \mathrm{mg} / \mathrm{ml}$ 'lik konsantrasyona kıyasla daha fazla sitotoksik etki gösterdikleri belirlendi $(\mathrm{p}<0.05)$. 

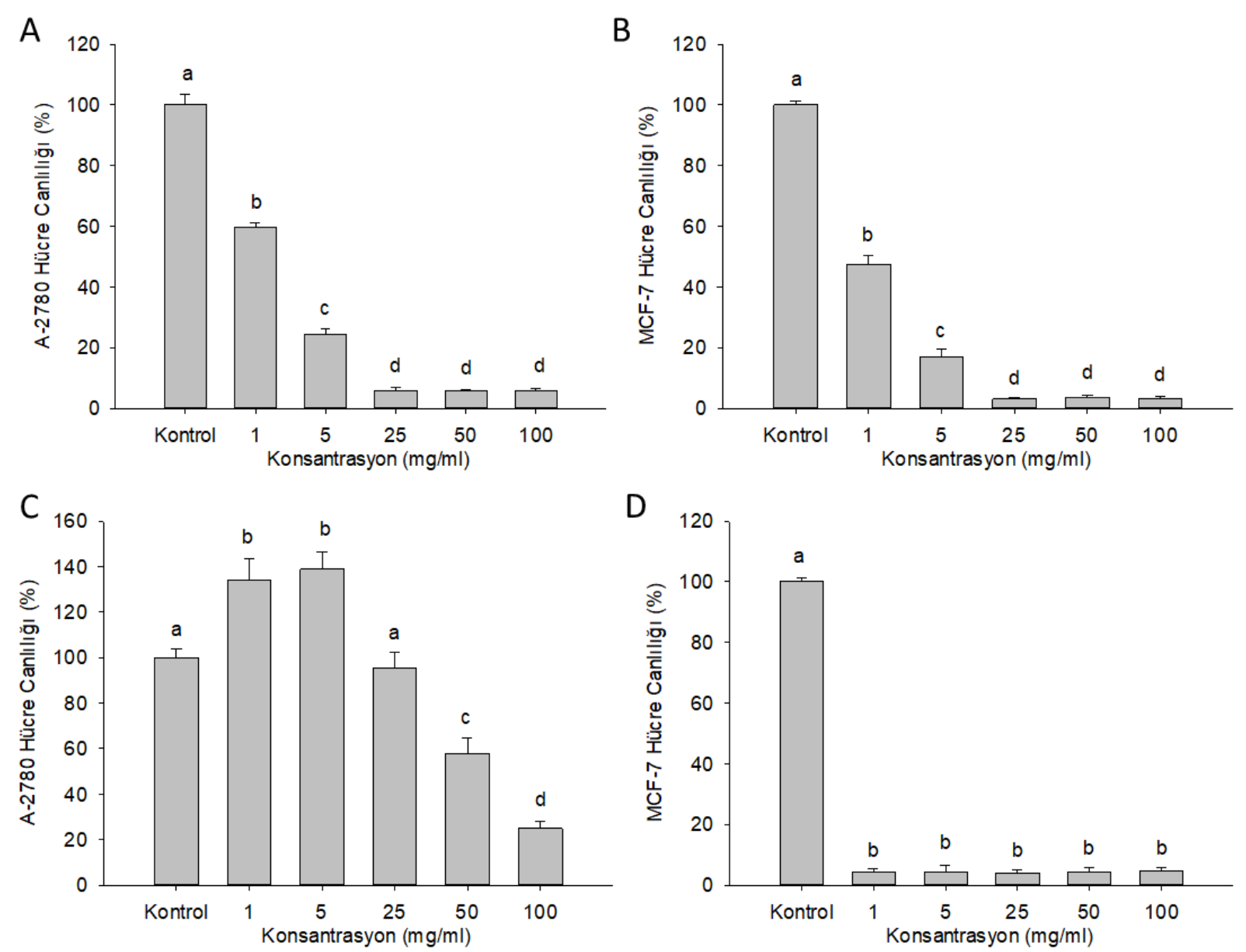

Şekil 1. Kudret narının dış (A-B) ve iç (C-D) kısımlarından elde edilen özütlerinin insan over ve meme kanseri hücre canlılıkları üzerine etkileri. Veriler ort. \pm SS olarak ifade edildi. ${ }^{\text {a-d }}$ birbirinden farklı, $\mathrm{p}<0.05$.
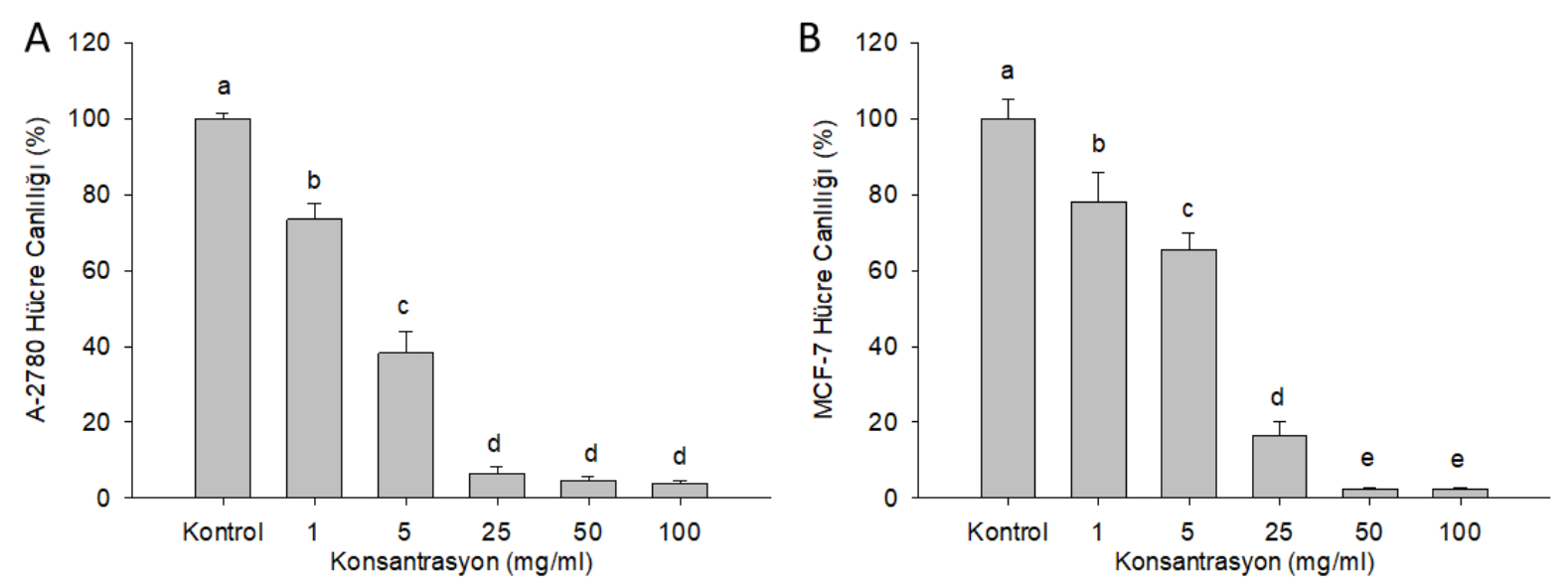

Şekil 2. Pepino özütünün insan over (A) ve meme kanseri hücre (B) canlılıkları üzerine etkileri. Veriler ort. \pm SS olarak ifade edildi. ${ }^{\mathrm{a}-\mathrm{e}}$ birbirinden farkl1, $\mathrm{p}<0.05$. 

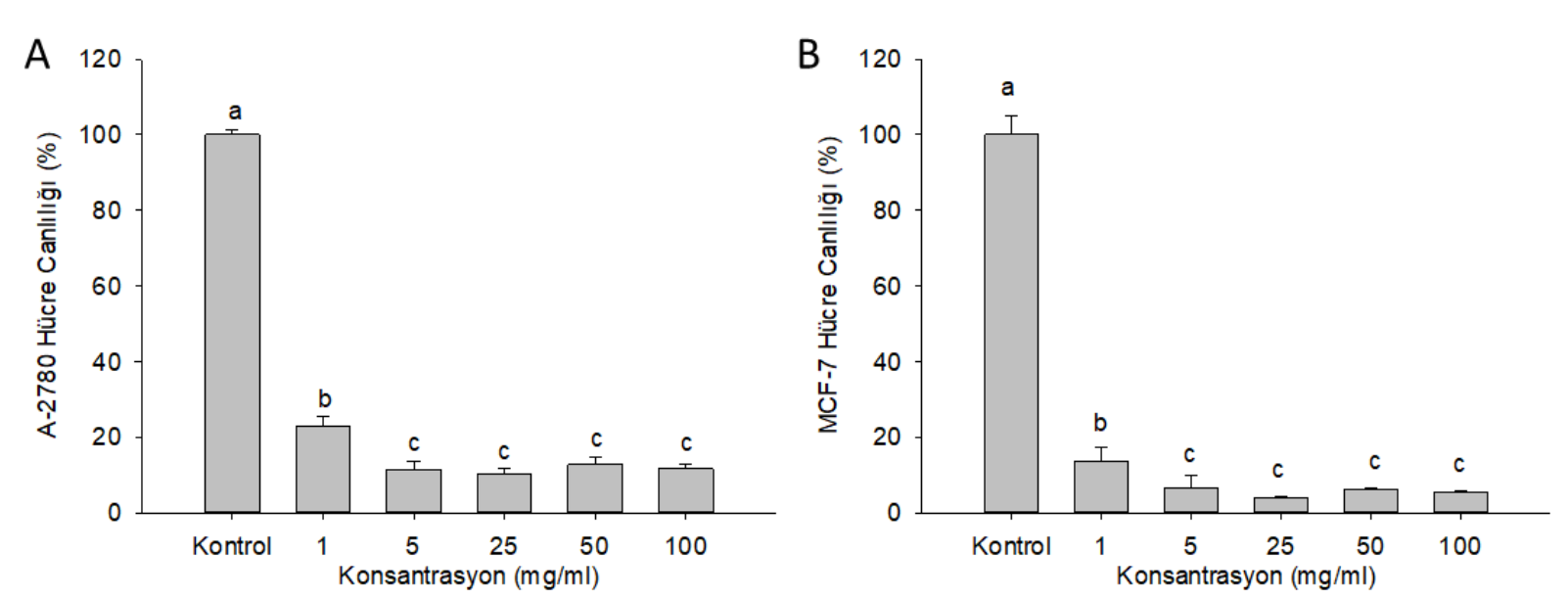

Şekil 3. Altın çilek özütünün insan over (A) ve meme kanseri hücre (B) canlılıkları üzerine etkileri. Veriler ort. \pm SS olarak ifade edildi. ${ }^{\mathrm{a}-\mathrm{c}}$ birbirinden farkl1, $\mathrm{p}<0.05$.

Kanser tedavisinde bitkisel kaynaklı ürünlerin kullanımı nispeten oluşabilecek sağlık sorunlarının önüne geçebilir. Bu yüzden son yıllarda antikanser ajan olarak kullanılan çeşitli bitki kaynaklarının kimyasal bileşenleriyle ilgili çalışmalar artmıştır [23]. Örneğin, soya fasulyesinden elde edilen curcumin, yeşil çaydan gelen polifenoller, üzümden resveratrol, domatesten likopen ve safrandan crocetin kanser tedavisinde etkili olan bileşiklerdir [24-26].

Yapılan çalışmalar kudret narından izole edilen BG-4 peptidinin ve özütün HCT-116 ve HT-29 kolon kanseri hücrelerinde Bcl-2 ekspresyonunu azaltıp, Bax ve kaspaz-3 ekspresyonların ise arttırarak apoptozu indüklediğini belirtmektedir [27,28]. Diğer bir çalışmada ise yine aynı bitki özütünün meme kanseri hücrelerinde mTOR/Akt sinyal yolağını inhibe ederek antikanser etki sergilediği gösterilmiştir [29]. Pepino bitki özütünün prostat (PC3, DU1445), mide (MKN45), karaciğer (QGY-7721, SK-HEP1), göğüs (MDA-MB-435), yumurtalık (OVCAR), kolon (HT29) ve akciğer (NCI-H209) kanser hücre hatlarında sitotoksik etki gösterdiği ve farelerde mide tümörünü küçültücü etki sergilediği rapor edilmiştir [30]. Ayrıca araştırmacılar deneysel kanser modeli çalışmalarında pepino özütü ile tedavinin metasıtazı azalttığını ve hayvanların yaşam süresini uzattığını göstermiştir [31, 32]. Diğer yandan altın çilek üzerine yapılan çalışmalarda bu bitkinin antikanser etkilere sahip olduğunu, altın çilek özütü uygulamasının akciğer, kolon ve hepatoselüler karsinom hücrelerinde proliferasyonu inhibe ettiğini bildirmektedir [33-35]. Literatürde belirten bu bulguların çalışmamızı destekler niteliktedir ve çalışmamızda araştırdığımız bitki özütleri farklı kanser serilerinde benzer etkiler ortaya koymaktadır. Sonuçlarımız özellikle $25 \mathrm{mg} / \mathrm{ml}$ konsatrasyon ve üstü uygulanan bütün özütlerin insan over ve meme kanseri hücre hatları üzerine güçlü sitotoksik etki sergilediğini ve bu söz konusu etkinin doza bağlı olarak artığını ortaya koymaktadır. Bitki özütlerinin kanser hücreleri üzerine gerçekleştirdiği bu sitotoksik etkinin içerdikleri vitaminler [36], polifenoller ve flavanoidler [37, 38] gibi antioksidan ve antikanser moleküllere bağlı olarak ortaya çıktığını düşünmekteyiz. Sonuç olarak farklı kanser türleri üzerine meydana gelen bu etkilerin mekanizmasını aydınlatmak için moleküler düzeyde çalışmalara ihtiyaç duyulmaktadır. Bu sayede yeni terapötiklerin insan kullanımına kazandırılması sağlanabilir.

\section{Sonuç ve Öneriler}

Bitkiler yüzyıllardır gıda ve ilaç amacıyla kullanılmaktadır ve bu geleneksel kullanımlar yüzyıllar boyunca denenmiş, test edilmiş ve nesilden nesile aktarılmıştır [39]. Dünya nüfusunun büyük bir kısmı, özellikle gelişmekte olan ülkelerde çeşitli hastalıklara karşı geleneksel tıbbi yöntemler kullanılmaktadır. Dünya Sağlık Örgütü, Dünya nüfusunun \%80'inin temel olarak geleneksel tıpta bitki özütlerinin veya bunların aktif bileşenlerinin kullandığını belirtmiştir [40]. Bu çalışmada tıbbi önemi olan kudret narı, pepino ve altın çilek türlerinin in vitro ortamda antioksidan ve antikanser etkilerini araştırıldı. Sonuç olarak her üç bitki örneğinin düşük seviyede antioksidan etki gösterdiğini, buna karşın A-2780 ve MCF7 kanser hücre hatları üzerine güçlü sitotoksik etki sergilediğini ortaya koyduk. Her üç örneğinde tıbbi açıdan önemli bitkiler olması ve halk tarafından kullanılması, bu bitkiler üzerine yapılacak yeni çalışmaların etki mekanizmalarını aydınlatmada yardımcı olacağını düşünmekteyiz. 


\section{Teşekkür}

Bu çalışma Bartın Üniversitesi Bilimsel Araştırma Projeleri Koordinasyon Birimi tarafından 2017-FENCY-003'nolu proje ile desteklenmiştir.

\section{Kaynaklar}

[1] Faydaoğlu E., Sürücüoğlu M.S. 2011. Geçmişten günümüze tıbbi ve aromatik bitkilerin kullanılması ve ekonomik önemi. Kastamonu Üniversitesi Orman Fakültesi Dergisi, 11:52-67.

[2] Dar R.A., Shahnawaz M., Qazi P.H. 2017. General overview of medicinal plants: A review, The Journal of Phytopharmacology, 6: 349-351.

[3] Ginwala R., Bhavsar R., Chigbu D.I., Jain P., Khan Z.K. 2019. Potential role of flavonoids in treating chronic inflammatory diseases with a special focus on the anti-inflammatory activity of apigenin. Antioxidants (Basel), 8 (2) e35.

[4] Rawat D., Shrivastava S., Naik R.A., Chhonker S.K., Mehrotra A., Koiri R.K. 2018. An overview of natural plant products in the treatment of hepatocellular carcinoma. Anti-Cancer Agents in Medicinal Chemistry, 18 (3): 1838 - 1859.

[5] Singh R. 2015. Medicinal plants: A review. Journal of Plant Sciences, 3:50-55.

[6] Hamburger M., Hostettmann K. 1991. 7. Bioactivity in plants: the link between phytochemistry and medicine. Phytochemistry, 30: 3864-3874.

[7] Desborough M.J.R., Keeling D.M. 2017. The aspirin story - from willow to wonder drug. British Journal of Haematology, 177: 674-683.

[8] Salehi B., Kumar N.V.A., Sener B., Sharifi-Rad M., Kilic M., Mahady G.B., Vlaisavljevic S., Iriti M., Kobarfard F., Setzer W.N., Ayatollahi S.A., Ata A., Sharifi-Rad J. 2018. Medicinal plants used in the treatment of human immunodeficiency virus. International Journal of Molecular Sciences, 19 (5): e1459.

[9] Rehman S., Ashfaq U.A., Ijaz B., Riazuddin S. 2018. Anti-hepatitis C virus activity and synergistic effect of Nymphaea alba extracts and bioactive constituents in liver infected cells. Microbial Pathogenesis, 121: 198-209.

[10] Doaei S., Hajiesmaeil M., Aminifard A., Mosavi-Jarrahi S.A., Akbari M.E., Gholamalizadeh M. 2018. Effects of gene polymorphisms of metabolic enzymes on the association between red and processed meat consumption and the development of colon cancer; a literature review. Journal of Nutritional Science, 7: e26.

[11] Singleton V.L., Rossi J.A. 1965. Colorimetry of total phenolics with phosphomolybdicphosphotungstic acid reagents. American Journal of Enology and Viticulture, 16:144-158.

[12] Çöteli E., Erden Y., Karataş F. 2013. Yarpuz (Mentha pulegium L.) bitkisindeki malondialdehit, glutatyon ve vitamin miktarları ile total antioksidan kapasitesinin araştırılması. Süleyman Demirel Üniversitesi Fen Bilimleri Enstitüsü Dergisi, 17 (2): 4-10.

[13] Brand-Williams W., Cuvelier M.E., Berset C. 1995. Use of a free radical method to evaluate antioxidant activity. LWT - Food Science and Technology, 28: 25-30.

[14] Tekin S., Erden Y., Sandal S., Yilmaz B. 2015. Is irisin an anticarcinogenic peptide? Medicine Science, 4: 2172-2180.

[15] Mosmann T. 1983. Rapid colorimetric assay for cellular growth and survival: application to proliferation and cytotoxicity assays. Journal of Immunological Methods, 65: 55-63.

[16] Güdr A. 2016. Influence of total anthocyanins from bitter melon (Momordica charantia Linn.) as antidiabetic and radical scavenging agents. Iranian Journal of Pharmaceutical Research, 15 (1): 301-9.

[17] Leelaprakash G., Rose J.C., Gowtham B., Javvaji P.K., Prasad S. 2011. In vitro antimicrobial and antioxidant activity of Momordica charantia leaves. Pharmacophore, 2: 244-252.

[18] Sen S., Chakraborty R., Borah B., Dey B., Sarkar B.R., Sahariah B. 2014. In vitro anthelmintic and antioxidant potential of fruits of Momordica charantia: A comparative study. Indian Journal of Health Sciences and Biomedical Research (KLEU), 7: 113.

[19] Sudha G., Sangeetha Priya M., Indhu Shree R.B., Vadivukkarasi S. 2012. Antioxidant activity of ripe and unripe pepino fruit (Solanum muricatum Aiton). Journal of Food Science, 77: C1131C1135. 
[20] Chang J., Lin C., Wu S., Lin D., Wang S., Miaw C., Ng L. 2008. Antioxidative and hepatoprotective effects of Physalis peruviana extract against acetaminophen-induced liver injury in rats. Pharmaceutical Biology, 46: 724-731.

[21] Koca N., Karadeniz F. 2005. Gıdalardaki doğal antioksidan bileşikler. Gıda/The Journal of Food, 30 (4): 229-236.

[22] Cook N., Samman S. 1996. Flavonoids - chemistry, metabolism, cardioprotective effects, and dietary sources. The Journal of Nutritional Biochemistry, 7: 66-76.

[23] Desai A.G., Qazi G.N., Ganju R.K., El-Tamer M., Singh J., Saxena A.K., Bedi Y.S., Taneja S.C., Bhat H.K. 2008. Medicinal plants and cancer chemoprevention. Current drug metabolism, 9: 581591.

[24] G Gutheil W., Reed G., Ray A., Anant S., Dhar A. 2012. Crocetin: an agent derived from saffron for prevention and therapy for cancer. Current Pharmaceutical Biotechnology, 13: 173-179.

[25] Aggarwal B.B., Shishodia S. 2006. Molecular targets of dietary agents for prevention and therapy of cancer. Biochemical Pharmacology, 71: 1397-1421.

[26] Lee B.M., Park K.K. 2003. Beneficial and adverse effects of chemopreventive agents. Mutation Research, 523-524: 265-278.

[27] Dia V.P., Krishnan H.B. 2016. BG-4, a novel anticancer peptide from bitter gourd (Momordica charantia), promotes apoptosis in human colon cancer cells. Scientific Reports, 6: 33532.

[28] Li C.J., Tsang S.F., Tsai C.H., Tsai H.Y., Chyuan J.H., Hsu H.Y. 2012. Momordica charantia extract induces apoptosis in human cancer cells through caspase- and mitochondria-dependent pathways. Evidence-Based Complementary and Alternative Medicine, 2012: 261971.

[29] Muhammad N., Steele R., Isbell T.S., Philips N., Ray R.B. 2017. Bitter melon extract inhibits breast cancer growth in preclinical model by inducing autophagic cell death. Oncotarget, 8: 66226-66236.

[30] Ren W., Tang D.G. 1999. Extract of Solanum muricatum (Pepino/CSG) inhibits tumor growth by inducing apoptosis. Anticancer Research, 19: 403-408.

[31] Shathish K., Guruvayoorappan C. 2014. Solanum muricatum Ait. inhibits inflammation and cancer by modulating the immune system. Journal of Cancer Research and Therapeutics, 10: 623630.

[32] Shathish K., Sakthivel K.M., Guruvayoorappan C. 2015. Protective effect of Solanum muricatum on tumor metastasis by regulating inflammatory mediators and nuclear factor-kappa B subunits. Journal of Environmental Pathology, Toxicology and Oncology, 34: 249-262.

[33] Wu S.J., Chang S.P., Lin D.L., Wang S.S., Hou F.F., Ng L.T. 2009. Supercritical carbon dioxide extract of Physalis peruviana induced cell cycle arrest and apoptosis in human lung cancer H661 cells. Food and Chemical Toxicology, 47: 1132-1138.

[34] Lee C.C., Chang W.H., Chang Y.S., Liu T.Y., Chen Y.C., Wu Y.C., Chang J.G. 2017. 4betahydroxywithanolide e modulates alternative splicing of apoptotic genes in human hepatocellular carcinoma Huh-7 Cells. Scientific Reports, 7: 7290.

[35] Chang L.C., Sang-Ngern M., Pezzuto J.M., Ma C. 2016. The Daniel K. Inouye College of Pharmacy Scripts: Poha berry (Physalis peruviana) with potential anti-inflammatory and cancer prevention activities. Hawai'i Journal of Medicine and Public Health, 75: 353-359.

[36] Ang A., Pullar J.M., Currie M.J., Vissers M.C.M. 2018. Vitamin C and immune cell function in inflammation and cancer. Biochemical Society Transactions, 46 (5): 1147-1159.

[37] Rengasamy K.R.R., Khan H., Gowrishankar S., Lagoa R.J.L., Mahomoodally F.M., Khan Z., Suroowan S., Tewari D., Zengin G., Hassan S.T.S., Pandian S.K. 2018. The role of flavonoids in autoimmune diseases: Therapeutic updates. Pharmacology and Therapeutics, 194: 107-131.

[38] Salehi B., Kumar N.V.A., Sener B., Sharifi-Rad M., Kilic M., Mahady G.B., Vlaisavljevic S., Iriti M., Kobarfard F., Setzer W.N., Ayatollahi S.A., Ata A., Sharifi-Rad J. 2018. Medicinal plants used in the treatment of human immunodeficiency virus. International Journal of Molecular Sciences, 19 (5): e1459.

[39] Prinsloo G., Nogemane N., Street R. 2018. The use of plants containing genotoxic carcinogens as foods and medicine. Food Chemical Toxicology, 116: 27-39.

[40] Gram H. 1993. Summary of WHO guidelines for the assessment of herbal medicines. Switzerland: World Health Organization, 13-14. 